Герасимова O.I.

\title{
Рефлексивні уміння як форма теоретичної діяльності майбутнього вчителя, спрямованої на самопізнання.
}

У статті розглядаються різні позищії науковиів на досліджувану проблему, проводиться порівняльний аналіз змісту категорій «рефлексія», «педагогічна рефлексія», «рефлексивні уміння».

Ключові слова: рефлексія, педагогічна рефлексія, рефлексивні уміння, самоаналіз, самопізнання.

B статье рассматриваются различные позищии ученых на исследуемую проблему, проводится сравнительный анализ содержания категорий «рефлексия», «педагогическая рефлексия», «рефлексивные умения».

Ключевые слова: рефлексия, педагогическая рефлексия, рефлексивные умения, самоанализ, самопознание.

The article deals with the different scientists' views to investigating problem, the comparative analysis of categories a «reflection», «pedagogical reflection», «reflexive skills» is carried out.

Key words: reflection, reflexive skills, introspection, self-knowledge.

Постановка проблеми. Гуманістична спрямованість освіти значною мірою визначається тим, що закладає в особистість механізм саморозвитку, саморегуляції задля здійснення ефективної життєдіяльності у сучасному соціумі. Для цього необхідно допомогти людині стати суб’ єктом діяльності, передусім, через виховання у неї рефлексивних умінь.

Труднощі рефлексивного характеру доволі часто виникають у студентів при здійсненні навчальної діяльності. Відсутність самопізнання, умінь аналізувати власні думки, неупереджено оцінювати свої можливості негативно впливають на процес навчання. 
Аналіз останніх досліджень і публікацій. Досліджувана проблема продовжує залишатися актуальною у психолого-педагогічній науці. Дослідження рефлексії було започатковане у працях видатних психологів Б. Ананьєва, Л. Виготського, В. Давидова, Д. Ельконіна, С. Рубінштейна і отримало своє продовження у розвідках сучасних науковців Н. Гуткіної, I. Семенова, С. Степанова, Р. Чумичевої, Г. Щедровицького та інших. Українська психолого-педагогічна наука також має чималі напрацювання у контексті відповідної проблематики (М. Боришевський, С. Васьківська, C. Максименко, В. Юрченко, Т. Яценко).У межах педагогіки рефлексія досліджувалась К.В. Вербовою, І.Ф. Ісаєвим, I.I. Казімірськой, Б.П. Ковалевим, С.В. Кондратьєвою, В.А. Кривошеєвим, Ю.Н. Кулюткіним, Л.М. Перміною, Є.Б. Петрушихіною, В.А. Сластьоніним, Г.Н. Сухобською та ін.

Мета даної статті полягає у тому, щоб з'ясувати теоретичні засади проблеми, спробувати дати порівняльний аналіз змісту категорій «рефлексія», «педагогічна рефлексія», «рефлексивні уміння».

Виклад основного матеріалу дослідження. Щодо поняття рефлексивних умінь науковці займають різні позиції. Розуміння особистісної рефлексії як знання учителем самого себе зустрічаємо Н. Маркової [5]. Такий же зміст вкладає у поняття «рефлексивні уміння» М. Вислогузова [1]. Водночас викликає сумнів доцільність поняття педагогічної рефлексії 3 визначення Б. Вульфова, В. Харкіна. На нашу думку, розглянута ними згадана категорія ідентична рефлексивним умінням. Г. Коджаспірова переконує: коли предметом рефлексії виступають усі сторони педагогічної діяльності учителя, то це - педагогічна рефлексія [3]. Ф. Гоноболін, Л. Кондрашова, В. Сластьонін також дотримуються подібної позиції. Рефлексивні уміння доцільно називати педагогічними, оскільки вони стають професійною рисою особистості вчителя, у його роботі набувають педагогічно спрямованого характеру. На їх думку, вони наповнюються новим педагогічним змістом і визначаються специфікою вчительської праці. 
Доречно завуажити, що дефініція «рефлексивні уміння» у психологопедагогічній літературі має різні трактування: «педагогічна рефлексія» (Г. Коджаспірова) [3], «професійно-педагогічна рефлексія» (Б. Вульфов, В. Харкін), «особистісна рефлексія» (Т. Щербакова), «саморефлексія» (М. Вислогузова) [1]. Довільне трактувасння термінології ускладнює розуміння суті рефлексивних умінь та дослідження окресленої проблеми.

На нашу думку, різниця полягає в їх змістовій характеристиці. Г. Коджаспірова, Н. Кузьміна, А. Маркова, Л. Мітіна, А. Реан, С. Рогов вважають рефлексію професійно-педагогічною властивістю, тотожною поняттю «здібність».

Формулювання А. Марковою визначення, що рефлексія - це здатність учителя подумки уявити собі в учневі картину ситуації і на цій основі уточнити уявлення про себе [5], підсумовує думки науковців указаного напрямку. Вона наголошує лише на здатності вчителя коригувати свою діяльність завдяки думці учнів («я очима інших»). Це одна з ознак рефлексії, і зокрема, рефлексивних умінь.

Науковець Г. Коджаспірова, досліджуючи проблеми педагогічної самоосвіти, зосереджує увагу на особистісному аспекті рефлексії і визначає іiі як усвідомлення, критичний аналіз та визначення шляхів продуктивного самовдосконалення своєї діяльності [3].

Щодо формування рефлексивних умінь у майбутніх педагогів, то варто наголосити на тому, що важливим завданням вищих педагогічних навчальних закладів є таке навчання і виховання студентів, яке дає змогу перевести особистісну позицію майбутніх педагогів із пасивного сприймання змісту професійної підготовки у позицію активного суб'єкта педагогічної діяльності.

Формулювання рефлексивних умінь у вітчизняних дослідженнях багато в чому збігаються з думками російського вченого А. Маркової. Вони розкривають їх як форму теоретичної діяльності, спрямованої на осмислення власних дій та їх законів і діяльності самопізнання, що пояснює сутність 
духовного світу людини 3 позицій усвідомлення нею того, як її сприймають інші.

Грунтуючись на перцептивно-рефлексивних здібностях учителя, розкриває зміст рефлексивних умінь Н. Кузьміна. Вона розглядає «три види відчуттів»: відчуття об’єкта, пов'язаного із симпатією й оцінкою, співвідношення потреб учнів до вимог (відчуття тих об’єктів навколишньої дійсності, які викликають в учнів найбільший емоційний відгук); відчуття міри чи такту (відчуття тих змін, які відбуваються в особистості під дією педагогічного впливу) і відчуття причетності (відчуття недоліків і переваг власної діяльності, які виявляються у взаємовідносинах з учнями) [4].

Беручи до уваги концепцію педагогічних здібностей, трактують зміст рефлексивних умінь А. Реан, С. Рогов. Вони доводять, що здібності звернені до об'єкта і суб'єкта педагогічного впливу, пов'язані зі специфічною чуттєвістю вчителя до власної особистості та особистості учня, тобто допомагають учителеві пізнавати завдяки особистості учня власну особистість. На основі цього визначають комплекс рефлексивноперцептивних умінь учителя:

- уміння пізнавати власні індивідуально-психологічні особливості;

- уміння оцінити свій психічний стан;

- уміння здійснити різнобічне сприймання й адекватне пізнання особистості учня і самого себе.

Інша група науковців: М. Вислогузова, Ю. Кулюткін, Л. Мітіна, Г. Сухобська розглядає педагогічну рефлексію як вид діяльності, що включає рефлексивні уміння. Зокрема, Л. Мітіна визначає рефлексію, виходячи зі структури особистості учителя в контексті схеми «діяльність-спілкуванняособистість». За ii твердженням, рефлексія - це самоаналіз діяльності вчителя, що грунтується на загальних принципах педагогічної діяльності [6]. Застосування цього поняття, на нашу думку, є досить обмеженим, оскільки характеризує рефлексію лише однією ознакою - самоаналізом. 
У дослідженнях щодо визначення особистісного аспекту рефлексії зроблено акцент на активізації принципу саморозвитку особистості. Згідно 3 цим визначається рефлексія, що забезпечує самоорганізацію й самомобілізацію особистості в різних умовах iï існування. Рефлексивні уміння виступають як процес осмислення особистісних змістів (образів особистості, 3 якими ототожнює себе «Я»), який приводить до їх поступальних змін та породжує новоутворення особистості. Поняття «особистісна рефлексія» у дослідженнях I. Беха, Н. Гуткіної, I. Семенова, I. Степанова розглядається в одному синонімічному ряду з поняттям «рефлексивних умінь».

Академік АПН України І. Бех порушив важливе питання, пов’язане 3 формуванням мотивації до особистісної рефлексії. Його вирішення забезпечує детермінацію діяльності індивіда, предметом якої виступає його образ «Я».

Рефлексивні уміння досліджується у працях Н. Гуткіної, І. Семенова, С. Степанова не тільки на теоретичному рівні, a доводиться експериментально $[2 ; 7 ; 8]$. Характерним для більшості цих робіт є розуміння рефлексивних умінь як дослідницького акту, спрямованого людиною на саму себе як суб'єкта життєдіяльності. Перше грунтовне дослідження щодо сутності особистісної рефлексії виконала Н. Гуткіна [2], яка розглядала зазначений феномен як механізм самосвідомості, особливий акт самодослідження, за якого індивід вивчає власний внутрішній світ і самого себе як дослідника. Проявом особистісної рефлексії в дослідженні виступили рефлексивні очікування, а критерієм наявності - самоаналіз, який визначає нові знання про себе. Н. Гуткіна встановила, що найбільш сензитивним періодом розвитку особистісної рефлексії є підлітковий вік. Ми досліджуємо процес виховання рефлексивних умінь в юнацькому віці, отже, маємо враховувати, що у цьому віковому періоді вона вже може бути виявленою та підлягає відповідній корекції, зумовленій особливостями професійної діяльності, до якої готуються студенти. 
У процесі виховання використовують такі види самоконтролю, як ненавмисний (мимовільний) та навмисний (довільний). Мимовільний самоконтроль можна здійснювати в структурі сприйняття, i він функціонуватиме автоматично. Його предметом є не діяльність взагалі, iіi мотиви, а лише ii процесуальна складова. Довільний самоконтроль визначається спеціальною метою і має важливі можливості стабілізації діяльності. Особистості, які свідомо ставлять перед собою мету в цій діяльності - здійснити окреслену програму, не відволікатися сторонніми справами, будуть спроможні більш систематично та послідовно виконувати свої професійні та суспільно корисні обов'язки.

Самоконтроль виконує функції стабілізації дій (реалізації програми дій усередині діяльності) та коригування (стабілізації) діяльності, згідно 3 іi мотивами та мотивацією. Саморегулювання передбачає готовність особистості адекватно сприймати вимоги навколишніх людей, аналізувати свої можливості, щоб успішно виконати поставлені вимоги: поєднує в собі уміння планувати власну діяльність, поведінку, згідно з тими умовами, в яких живе людина, тих внутрішніх можливостей, якими вона володіє. Саморегулювання вимагає готовності висувати вимоги до самого себе та уміння гальмувати ті прагнення, котрі суперечать зовнішнім умовам i внутрішнім можливостям особистості.

Таким чином, рефлексію можна розглядати як специфічну форму педагогічної діяльності, що включає саморефлексію, спрямовану на осмислення індивідом своїх власних дій, які ми характеризуємо як рефлексивні. При цьому важливо зазначити, що рефлексивні уміння - не просто знання чи розуміння суб'єктом у педагогічній діяльності самого себе, але й вивчення того, як інші (учні, колеги, батьки) знають і розуміють «рефлексованого», його особистісні якості, емоційні реакції та когнітивні уявлення [6].

Доречно відзначити зв’ язок рефлексивних умінь педагога з вирішенням головної мети виховання - формування особистості вихованців. Розвиток 
особистісно рівноправних, співтворчих відносин між учителем й учнем передбачає здатність до рефлексивних умінь, тобто самокритичність, самоаналіз, самооцінку своїх дій учителем 3 пріоритетною орієнтацією на особистість учня. В особистісному аспекті рефлексивні уміння, з одного боку, виступають як здатність людини до самоаналізу, сприяє розвитку самосвідомості та $є$ важливим фактором особистісного самовдосконалення, а 3 іншого, - виведення мислення на рефлексивний рівень детермінується особистісними цінностями, стосунками, переживаннями. Рефлексивні уміння здійснюють вплив на сферу міжособистісних контактів, що передбачають доступність власного досвіду людини для іншого й відкритість досвіду іншого для себе.

До виховного потенціалу рефлексивних умінь варто віднести такі іiі особливості:

- рефлексивні уміння як здатність людини до аналізу, осмислення i переосмислення своїх відносин із навколишнім світом, $є$ необхідною складовою частиною особистісного розвитку;

- рефлексивні уміння дають змогу людині свідомо регулювати, контролювати свою поведінку та усвідомлювати іiі значення для інших людей;

- рефлексивні уміння сприяють цілісності та динамізму внутрішнього життя людини, а також справляють позитивний вплив на сферу міжособистісних взаємин.

Рефлексивні уміння передбачають усвідомлення своїх особистісних якостей у зв'язку зі специфікою фаху. Структуру рефлексивних умінь складають: самопізнання, самооцінка, самоаналіз, самоконтроль.

Рефлексивні уміння майбутнього учителя як цілеспрямований, самостійний, мотивований процес осмислення і переосмислення свого «Я» у вимірах обраного фаху визначає суб'єктність майбутнього педагога та перспективи його становлення за період навчання у вищому педагогічному навчальному закладі. 
Отже, рефлексивні уміння - це вид діяльності, спрямований на самопізнання й усвідомлення того, як особу сприймають інші люди. У процесі педагогічної діяльності рефлексивні уміння спрямовують на аналіз та коригування педагогічних технологій, які застосовують для досягнення конкретної мети навчально-виховного процесу, а також на особистість педагога.

\section{Література}

1. Вислогузова М.А. Подготовка учителя к творческой деятельности / Маргарита Анатольевна Вислогузова. - М. : Прометей, 1993. - 70 с.

2. Гуткина Н.И. Личностная рефлексия в подростковом розросте : автореф. дисс. на соискание уч. степени канд. психол. наук : спец. 19.00.07 «Педагогическая и возрастная психология» / Н.И. Гуткина. M., 1983. $-24 \mathrm{c}$.

3. Коджаспирова Г.М. Культура профессионального самообразования педагога / Галина Михайловна Коджаспирова. - М. : Издательский центр «Академия», 1994. - 147 с.

4. Кузьмина Н.В. Профессионализм личности преподавателя и мастера производственного обучения / Нина Васильевна Кузьмина. - М. : Высш. школа, 1990. - 117, [2] с.

5. Маркова А.К. Психология профессионализма / Аэлита Капитоновна Маркова. - М. : Знание, 1997. - 308 с.

6. Митина Л.М. Психология профессионального развития учителя / Лариса Максимовна Митина. - М. : Флинта, 1998. - 236 с.

7. Семенов И.Н. Проблемы рефлексивной психологии решения творческих задач / Игорь Никитович Семенов. - М. : НИИ общей и пед. психологии, 1990. - 215 с.

8. Степанов С.Ю. Проблема формирования типов рефлексии в решении творческих задач / С.Ю. Степанов, И.Н. Семёнов // Вопросы психологии. - 1982. - № 1. - С. 99-104. 